\title{
MalVac: Database of malarial vaccine candidates
} Rupanjali Chaudhuri ${ }^{\dagger}$, Shakil Ahmed ${ }^{\dagger}$, Faraz Alam Ansari ${ }^{\dagger}$,
Harinder Vir Singh and Srinivasan Ramachandran*

Address: G.N Ramachandran Knowledge Centre for Genome Informatics, Institute of Genomics and Integrative Biology (Council of Scientific and Industrial Research), Mall Road, Delhi 110007, India

Email: Rupanjali Chaudhuri - rupanjali.bhu@gmail.com; Shakil Ahmed - rajshakil@gmail.com; Faraz Alam Ansari - faraz7862@rediffmail.com; Harinder Vir Singh - harinder_vir_singh@yahoo.com; Srinivasan Ramachandran* - ramuigib@gmail.com

* Corresponding author †Equal contributors

Published: 23 September 2008

Malaria Journal 2008, 7:184 doi:10.1186/1475-2875-7-184
Received: 26 July 2008

Accepted: 23 September 2008

This article is available from: http://www.malariajournal.com/content/7////84

(C) 2008 Chaudhuri et al; licensee BioMed Central Ltd.

This is an Open Access article distributed under the terms of the Creative Commons Attribution License (http://creativecommons.org/licenses/by/2.0), which permits unrestricted use, distribution, and reproduction in any medium, provided the original work is properly cited.

\begin{abstract}
Background: The sequencing of genomes of the Plasmodium species causing malaria, offers immense opportunities to aid in the development of new therapeutics and vaccine candidates through Bioinformatics tools and resources.

Methods: The starting point of MalVac database is the collection of known vaccine candidates and a set of predicted vaccine candidates identified from the whole proteome sequences of Plasmodium species provided by PlasmoDb 5.4 release (3Ist October 2007). These predicted vaccine candidates are the adhesins and adhesin-like proteins from Plasmodium species, Plasmodium falciparum, Plasmodium vivax and Plasmodium yoelii. Subsequently, these protein sequences were analysed through 20 publicly available algorithms to obtain Orthologs, Paralogs, BetaWraps, TargetP, TMHMM, SignalP, CDDSearch, BLAST with Human Ref. Proteins, T-cell epitopes, B-cell epitopes, Discotopes, and allergen predictions. All of this information was collected and organized with the ORFids of the protein sequences as primary keys. This information is relevant from the view point of Reverse Vaccinology in facilitating decision making on the most probable choice for vaccine strategy.
\end{abstract}

Results: Detailed information on the patterning of the epitopes and other motifs of importance from the viewpoint of reverse vaccinology has been obtained on the most probable protein candidates for vaccine investigation from three major malarial species. Analysis data are available on 161 adhesin proteins from P. falciparum, 137 adhesin proteins from P. vivax and 34 adhesin proteins from $P$. yoelii. The results are displayed in convenient tabular format and a facility to export the entire data has been provided. The MalVac database is a "community resource". Users are encouraged to export data and further contribute by value addition. Value added data may be sent back to the community either through MalVac or PlasmoDB.

Conclusion: A web server MalVac for facilitation of the identification of probable vaccine candidates has been developed and can be freely accessed. 


\section{Background}

Malaria is a major killer disease. Annually, about 500 million people get infected and an estimated 1 million deaths occur. Despite numerous efforts we still do not have effective vaccines [1]. Among the parasites that cause malaria, the most common and widely distributed is Plasmodium vivax [2]. But the most fatal form of malaria is caused by Plasmodium falciparum [3]. Plasmodium yoelii is a commonly used rodent malaria parasite as a model to study malaria infection. Malaria caused by $P$. yoelii has similarities to that caused by P. falciparum and P. vivax [4].

Currently, several vaccines against multiple stages are in clinical development, including pre-erythrocytic, blood stage and others [3]. Although these advancements raise the hopes of the availability of an effective vaccine, it is noted that our limited knowledge on the details of the immune responses is becoming a major handicap [1]. The availability of complete genome sequences of Plasmodium falciparum [5], P. yoelii [4] and P. vivax has provided new opportunity for applying the principles of Reverse Vaccinology. Reverse vaccinology uses bioinformatics in the initial steps to identify potential antigens, which are subsequently examined for their efficacy and toxicity. In its maiden application, use of algorithm for prediction of sub-cellular location boosted the power of identifying potential vaccine candidates [6]. Subsequently, enhancements have been proposed to reverse vaccinology by suggesting the use of additional algorithms to find probability of being an adhesin, of topology (transmembrane regions) and to find similarity with host protein [7].

Recently, integrative approaches are proposed for Reverse Vaccinology by including prediction of multiple features of proteins [8]. Adopting this strategy, the following predictions were incorporated: of adhesins [9] and their orthologs [10], paralogs [11], transmembrane topologies [12], beta helix supersecondary structural motifs [13], subcellular localization $[14,15]$, similarity against Human proteins [16], antigenic regions [17], conserved domains [18], epitopes [19-26] and allergens [27-29]. The work flow started with adhesin prediction algorithm, which holds an important position in vaccine development process. The adhesin proteins mediate the adherence of malaria parasites to the host cells and facilitate invasion. Targeting these adhesins to abrogate the colonization process can prevent malaria infection $[9,30]$.

The multiple features of potential vaccine candidates coupled with information on the current candidates being pursued can be queried through a user friendly interface. These data are housed in MalVac database, which can aid in the discovery of adhesin based vaccines.

\section{Methods \\ Database architecture}

The ORF identification tags (ORF ID) assigned to proteins of malaria parasites as given in PlasmoDB 5.4 release of $31^{\text {st }}$ October 2007 [31] were used as primary keys. The database was developed using MySQL version 4.1.20 at back end and operated in Red Hat Enterprise Linux ES release 4 . The web interfaces have been developed in HTML and PHP 5.1.4, which dynamically execute the MySQL queries to fetch the stored data and is run through Apache 2 server. The overall layout of MalVac is provided in Figure 1.

The first step towards MalVac database creation is the collection of known vaccine candidates and a set of predicted vaccine candidates identified from the whole proteome sequences of Plasmodium species provided by PlasmoDB 5.4 release(31st October 2007). These predicted vaccine candidates are the adhesins and adhesin-like proteins from Plasmodium species, $P$. falciparum, $P$. vivax and $P$. yoelii using MAAP server [9]. Subsequently these protein sequences were analysed with 20 algorithms important from the view of reverse vaccinology (Table 1).

\section{Database access and interface}

MalVac Database is freely available [32]. A user friendly web-based interface allows users to explore the site and fetch the data corresponding to their queries. For example, if the user needs to search database for data on a set of proteins given by their ORF identification tags one starts with clicking the "Database Search" button (Figure 2). This would take the user to the "MalVac Query Page". Here the user can search the database for adhesin proteins and their attributes corresponding to one or more ORF identification tags of a species or against a specific Keyword. To fetch the required data the corresponding checkboxes need to be toggled 'on' followed by clicking the submit button (Figure 3 ). The results are displayed in convenient tabular format and a facility to export the entire data has been provided. To get the Epitope and Allergen data the user must provide a specific ORF ID along with the species selected.

Advanced search facility of predicted malarial adhesins is also provided where the results can be filtered on the basis of Protein length, number of transmembrane spanning regions, localization and reliability class, presence or absence of betawraps, paralogs, orthologs, hits to Conserved Domain Database and Human Reference proteins (retrieved from NCBI through ftp on April 22, 2008). The results obtained can be exported by the user. The known vaccines link takes user to the page containing the list of known vaccine candidates provided in tabular form. This data can again be exported by the user. Facility to post comments by the user has been provided in MalVac web 


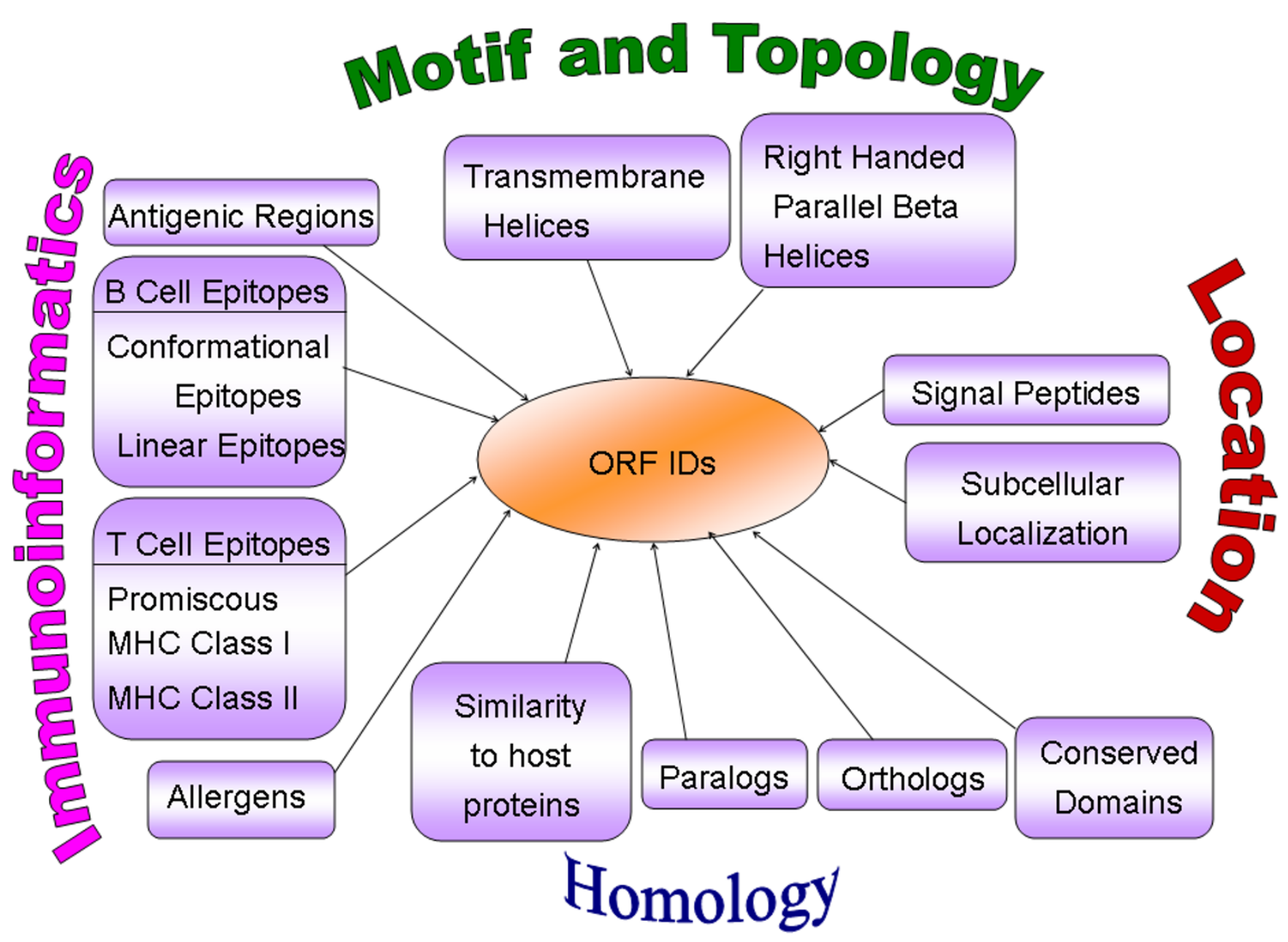

Figure I

The MalVac layout. All data are organized in relation to the primary key ORF ID.

interface. Users can post their value added comments and suggestions on specific genes based on their own experience through the comment posting page of MalVac.

\section{Results and Discussion}

MalVac Database contains analysis data on 332 potential vaccine candidates on three most important Plasmodium species. Of these, 161 are from $P$. falciparum, 137 are from $P$. vivax and 34 are from $P$. yoelii. First level of searching and retrieval of data is possible either through ORF ID or keywords. Multiple ORF IDs can be submitted using comma separation. Keywords can be used singly. If multiple keywords are used then the search is implemented using the AND Boolean. In the case of searching for epitope data, due to their huge size, data are conveniently retrieved in a singular mode for each ORF ID specifically. All data can be exported conveniently as a text file.

The database houses detailed information on these vaccine candidates analysed through 20 algorithms impor- tant from the view of reverse vaccinology. The analysis through these algorithms provide a broad range of information regarding Orthologs, Paralogs, BetaWraps, Localization, Transmembrane spanning regions, Signal Peptides, Conserved domains, similarity to Human Reference Proteins, T-cell epitopes, B-cell epitopes, Discotopes, and Allergen predictions.

Advanced level searches are also provided. In this facility users can search using combined feature selection. The most immediate application of such a scheme is in filtering for candidate proteins meeting a certain set of specifications. For example users formulate their queries by selecting for proteins that have less (or greater) than a specified number of transmembrane domains and less (or greater) than a specified length of protein. The features on which users can formulate their search could be based on Protein length, number of transmembrane spanning regions, localization-reliability class, presence or absence of betawraps, paralogs, orthologs, hits to CDD and 
Table I: Algorithms used to predict molecular features of potential malarial vaccine candidates and housed in MalVac.

\begin{tabular}{|c|c|c|c|}
\hline Algorithm & Principle & Role in MalVac & Reference \\
\hline I. MAAP & $\begin{array}{l}\text { Predicts Malarial adhesins and adhesins-like proteins based on } \\
\text { Support Vector Machines }\end{array}$ & $\begin{array}{l}\text { Adhesin and Adhesin like } \\
\text { protein prediction. }\end{array}$ & [9] \\
\hline 2. BLASTCLUST & $\begin{array}{l}\text { Clusters protein or DNA sequences based on pair wise } \\
\text { matches found using the BLAST algorithm in case of proteins } \\
\text { or Mega BLAST algorithm for DNA. }\end{array}$ & Paralogs finding & {$[\mathrm{II}]$} \\
\hline 3. TMHMM Server v. 2.0 & $\begin{array}{l}\text { Predicts the transmembrane helices in proteins based on } \\
\text { Hidden Markov Model. }\end{array}$ & $\begin{array}{l}\text { Transmembrane helices } \\
\text { prediction }\end{array}$ & {$[12]$} \\
\hline 4. BetaWrap & $\begin{array}{l}\text { Predicts the right-handed parallel beta-helix supersecondary } \\
\text { structural motif in primary amino acid sequences by using } \\
\text { beta-strand interactions learned from non-beta-helix } \\
\text { structures. }\end{array}$ & Betawrap finding & {$[13]$} \\
\hline 5. TargetPI.I & $\begin{array}{l}\text { Predicts the subcellular location of eukaryotic proteins based } \\
\text { on the predicted presence of any of the N-terminal } \\
\text { presequences: chloroplast transit peptide (cTP), } \\
\text { mitochondrial targeting peptide ( } \mathbf{m T P} \text { ) or secretory pathway } \\
\text { signal peptide (SP). }\end{array}$ & Localization Prediction. & {$[14]$} \\
\hline 6. SignalP 3.0 & $\begin{array}{l}\text { Predicts the presence and location of signal peptide cleavage } \\
\text { sites in amino acid sequences from different organisms. The } \\
\text { method incorporates a prediction of cleavage sites and a signal } \\
\text { peptide/non-signal peptide prediction based on a combination } \\
\text { of several artificial neural networks and hidden Markov } \\
\text { models. }\end{array}$ & Signal Peptide Prediction. & {$[15]$} \\
\hline 7. BlastP & $\begin{array}{l}\text { It uses the BLAST algorithm to compare an amino acid query } \\
\text { sequence against a protein sequence database. }\end{array}$ & $\begin{array}{l}\text { Prediction of similarity to human } \\
\text { reference proteins. }\end{array}$ & {$[16]$} \\
\hline 8. Antigenic & $\begin{array}{l}\text { Predicts potentially antigenic regions of a protein sequence, } \\
\text { based on occurrence frequencies of amino acid residue types } \\
\text { in known epitopes. }\end{array}$ & Antigenic region prediction. & {$[17]$} \\
\hline $\begin{array}{l}\text { 9. Conserved Domain Database } \\
\text { and Search Service, v2.13 }\end{array}$ & $\begin{array}{l}\text { The Database is a collection of multiple sequence alignments } \\
\text { for ancient domains and full-length proteins. It is used to } \\
\text { identify the conserved domains present in a protein query } \\
\text { sequence. }\end{array}$ & Conserved Domain Finding & {$[18]$} \\
\hline 10. ABCPred & $\begin{array}{l}\text { Predict } B \text { cell epitope(s) in an antigen sequence, using artificial } \\
\text { neural network. }\end{array}$ & Linear B Cell Epitope Prediction. & {$[19]$} \\
\hline II. BcePred & $\begin{array}{l}\text { Predicts linear B-cell epitopes, using physico-chemical } \\
\text { properties. }\end{array}$ & Linear B Cell Epitope Prediction. & {$[20]$} \\
\hline 12. Discotope I.I & $\begin{array}{l}\text { Predicts discontinuous B cell epitopes from protein three } \\
\text { dimensional structures utilizing calculation of surface } \\
\text { accessibility (estimated in terms of contact numbers) and a } \\
\text { novel epitope propensity amino acid score. }\end{array}$ & $\begin{array}{l}\text { Conformational B Cell Epitope } \\
\text { Prediction. }\end{array}$ & {$[2 I]$} \\
\hline I3. CEP & $\begin{array}{l}\text { The algorithm predicts epitopes of protein antigens with } \\
\text { known structures. It uses accessibility of residues and spatial } \\
\text { distance cut-off to predict antigenic determinants (ADs), } \\
\text { conformational epitopes (CEs) and sequential epitopes (SEs). }\end{array}$ & $\begin{array}{l}\text { Conformational B Cell Epitope } \\
\text { Prediction }\end{array}$ & {$[22]$} \\
\hline 14. NetMHC 2.2 & $\begin{array}{l}\text { Predicts binding of peptides to a number of different HLA } \\
\text { alleles using artificial neural networks (ANNs) and weight } \\
\text { matrices. }\end{array}$ & HLA Class I Epitope prediction. & {$[23]$} \\
\hline I5. MHCPred 2.0 & $\begin{array}{l}\text { MHCPred uses the additive method to predict the binding } \\
\text { affinity of major histocompatibility complex (MHC) class I and } \\
\text { II molecules and also to the Transporter associated with } \\
\text { Processing (TAP). Allele specific Quantitative Structure } \\
\text { Activity Relationship (QSAR) models were generated using } \\
\text { partial least squares (PLS). }\end{array}$ & $\begin{array}{l}\text { MHC Class I and II epitope } \\
\text { prediction. }\end{array}$ & {$[24]$} \\
\hline 16. Bimas & $\begin{array}{l}\text { Ranks potential 8-mer, 9-mer, or } 10 \text {-mer peptides based on a } \\
\text { predicted half-time of dissociation to HLA class I molecules. } \\
\text { The analysis is based on coefficient tables deduced from the } \\
\text { published literature by Dr. Kenneth Parker, Children's } \\
\text { Hospital Boston. }\end{array}$ & HLA Class I Epitope prediction. & {$[25]$} \\
\hline 17. Propred & $\begin{array}{l}\text { Predicts MHC Class-II binding regions in an antigen sequence, } \\
\text { using quantitative matrices derived from published literature. } \\
\text { It assists in locating promiscous binding regions that are useful } \\
\text { in selecting vaccine candidates. }\end{array}$ & $\begin{array}{l}\text { Promiscous MHC Class II } \\
\text { epitope prediction. }\end{array}$ & {$[26]$} \\
\hline
\end{tabular}


Table I: Algorithms used to predict molecular features of potential malarial vaccine candidates and housed in MalVac. (Continued)

\begin{tabular}{|c|c|c|c|}
\hline 18. AlgPred & $\begin{array}{l}\text { Predicts allergens in query protein based on similarity to } \\
\text { known epitopes, searching MEME/MAST allergen motifs using } \\
\text { MAST and assign a protein allergen if it have any motif, search } \\
\text { based on SVM modules and search with BLAST search against } \\
2890 \text { allergen-representative peptides obtained from } \\
\text { Bjorklund et al } 2005 \text { and assign a protein allergen if it has a } \\
\text { BLAST hit. }\end{array}$ & Allergen Prediction & [27] \\
\hline 19. Allermatch & $\begin{array}{l}\text { Predicts the potential allergenicity of proteins by } \\
\text { bioinformatics approaches as recommended by the Codex } \\
\text { alimentarius and FAO/WHO Expert consultation on } \\
\text { allergenicity of foods derived through modern biotechnology. }\end{array}$ & Allergen Prediction & [28] \\
\hline 20. WebAllergen & $\begin{array}{l}\text { Predicts the potential allergenicity of proteins. The query } \\
\text { protein is compared against a set of pre-built allergenic motifs } \\
\text { that have been obtained from } 664 \text { known allergen proteins. }\end{array}$ & Allergen Prediction & [29] \\
\hline
\end{tabular}

human reference proteins in the advanced search page. The results obtained can be exported by the user.

\section{Conclusion}

MalVac database was built as a community resource to aid malaria vaccinologists. MalVac is freely available with facility to export data and use for user's convenience [32].

\section{Competing interests}

The authors declare that they have no competing interests.

\section{Authors' contributions}

SR conceived the idea and provided guidance, suggestions, critical comments, and testing of MalVac. RG, SA, FAA, HVS collected data, organized systematically, prepared the codes for MalVac. SR and RG wrote the manuscript. All authors read and approved the final manuscript.

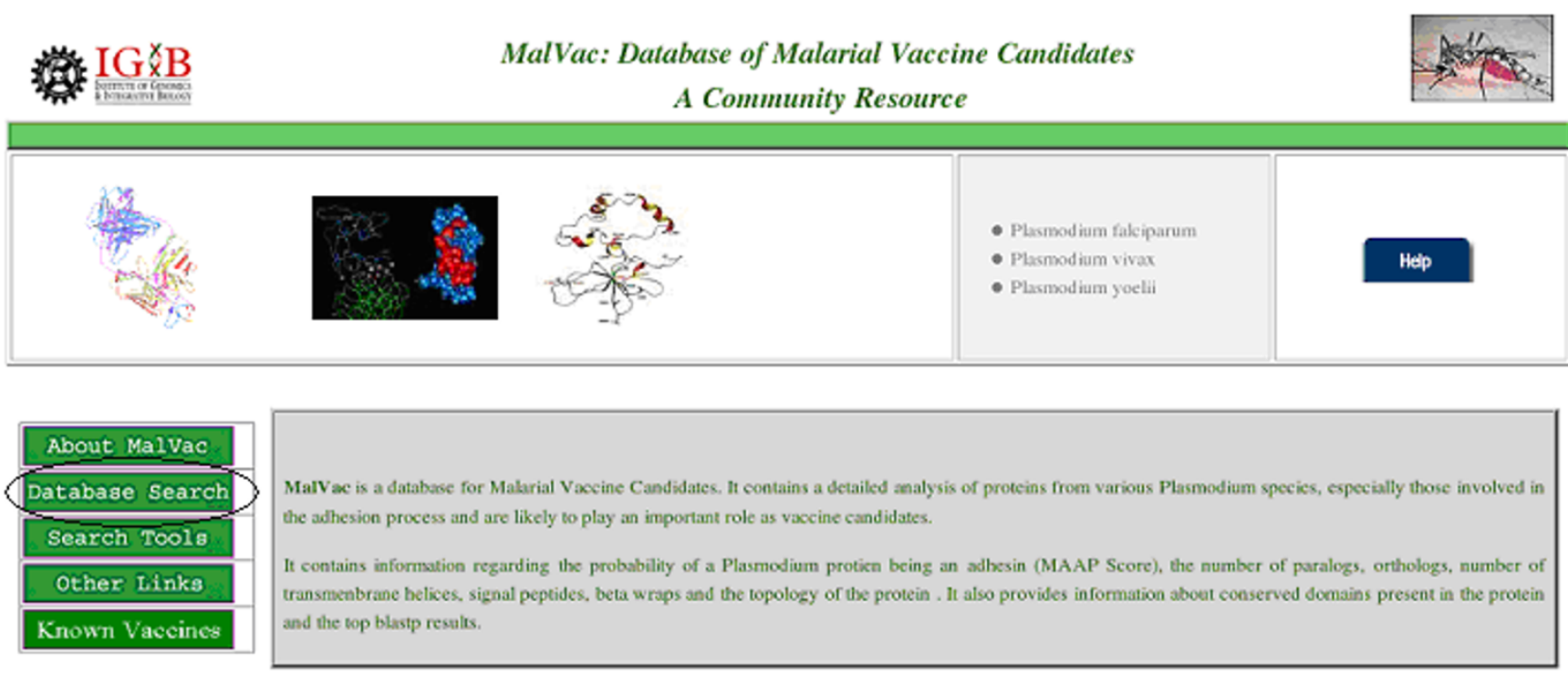

\section{Figure 2}

The Home page of MalVac. The "Database Search" facility can be used for first level search. Advanced search is provided in the "Search Tools" facility. "Other links" would take users to other websites of malaria for obtaining additional details and the "Known Vaccines" tab describes the details of the currently known vaccine candidates. 

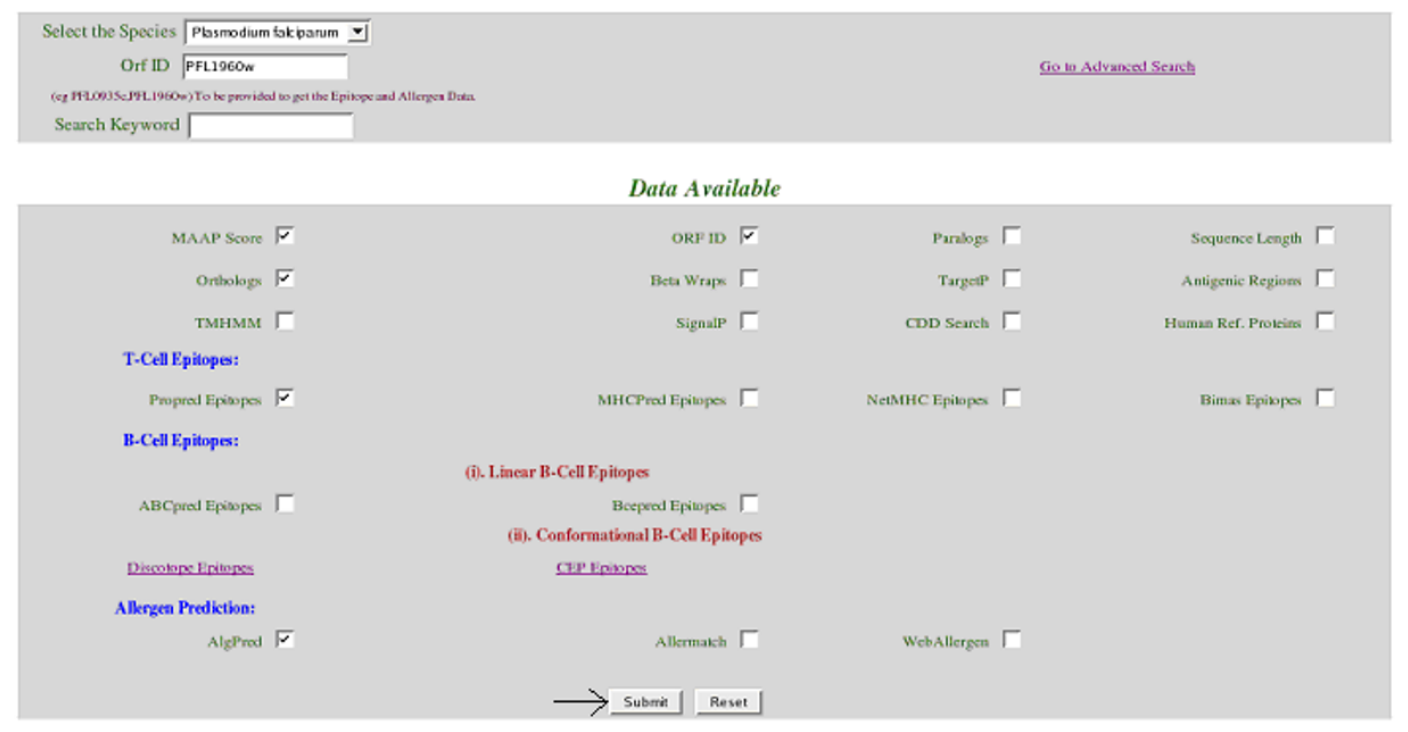

Any Suggestions? Past your comments, Show Previous Comments

Figure 3

The MalVac Query Page. Default selections are MAAP score and ORF ID.

\section{Acknowledgements}

SR thanks the NMITLI project on Plasmodium falciparum annotation and CMM00 I7 Task force on "Drug target development using in silico biology" for financial support and Raghunandan for systems support. RG thanks ICMR for a fellowship.

\section{References}

I. Thompson J, Millington OR, Garside P, Brewer JM: What can transgenic parasites tell us about the development of Plasmodiumspecific immune responses? Parasite Immunol 2008, 30:223-233.

2. Sina B: Focus on Plasmodium vivax. Trends Parasitol 2002, 18:287-289.

3. Todryk SM, Hill AV: Malaria Vaccines: the stage we are at. Nat Rev Microbiol 2007, 5:487-489.

4. Carlton JM, Angiuoli SV, Suh BB, Kooij TW, Pertea M, Silva JC, Ermolaeva MD, Allen JE, Selengut JD, Koo HL, Peterson JD, Pop M, Kosack DS, Shumway MF, Bidwell SL, Shallom SJ, van Aken SE, Riedmuller SB, Feldblyum TV, Cho JK, Quackenbush J, Sedegah M, Shoaibi A, Cummings LM, Florens L, Yates JR, Raine JD, Sinden RE, Harris MA, Cunningham DA, Preiser PR, Bergman LW, Vaidya $A B$, van Lin $L H$, Janse CJ, Waters AP, Smith HO, White OR, Salzberg SL, Venter JC, Fraser CM, Hoffman SL, Gardner MJ, Carucci DJ: Genome sequence and comparative analysis of the model rodent malaria parasite Plasmodium yoelii yoelii. Nature 2002, 419:5।2-5I9.

5. Gardner MJ, Hall N, Fung E, White O, Berriman M, Hyman RW, Carlton JM, Pain A, Nelson KE, Bowman S, Paulsen IT, James K, Eisen JA, Rutherford K, Salzberg SL, Craig A, Kyes S, Chan MS, Nene V, Shallom SJ, Suh B, Peterson J, Angiuoli S, Pertea M, Allen J, Selengut J, Haft $D$, Mather MW, Vaidya AB, Martin DM, Fairlamb AH, Fraunholz MJ, Roos DS, Ralph SA, McFadden GI, Cummings LM, Subramanian GM, Mungall C, Venter JC, Carucci DJ, Hoffman SL, Newbold C, Davis RW, Fraser CM, Barrell B: Genome sequence of the human malaria parasite Plasmodium falciparum. Nature 2002, 419:498-5II.

6. Serruto D, Rappuoli R: Post-genomic vaccine development. FEBS Lett 2006, 580:2985-2992.

7. Vivona S, Bernante F, Filippini F: Nerve: New Enhanced Reverse Vaccinology Environment. BMC Biotechnol 2006, 6:35.

8. Vivona S, Gardy JL, Ramachandran S, Brinkman FS, Raghava GP, Flower DR, Filippini F: Computer-aided biotechnology: from immuno-informatics to reverse vaccinology. Trends Biotechnol 2008, 26:190-200.

9. Ansari FA, Kumar N, Bala Subramanyam M, Gnanamani M, Ramachandran S: MAAP: Malarial adhesins and adhesin-like proteins predictor. Proteins 2008, 70:659-666.

10. Chen F, Mackey AJ, Stoeckert CJ Jr, Roos DS: OrthoMCL-DB: querying a comprehensive multi-species collection of ortholog groups. Nucleic Acid Res 2006:D363-368.

II. Kondrashov FA, Rogozin IB, Wolf YI, Koonin EV: Selection in the evolution of gene duplications. Genome Biol 2002, 3:RESEARCH0008.

12. Krogh A, Larsson B, von Heijne G, Sonnhammer EL: Predicting transmembrane protein topology with a hidden Markov model: application to complete genomes. J Mol Biol 200I, 305:567-580.

13. Bradley P, Cowen L, Menke M, King J, Berger B: BETAWRAP: successful prediction of parallel beta-helices from primary sequence reveals an association with many microbial pathogens. Proc Natl Acad Sci USA 200I, 98: I 48 I 9- I 4824.

14. Emanuelsson O, Nielsen H, Brunak S, von Heijne G: Predicting subcellular localization of proteins based on their $\mathbf{N}$-terminal amino acid sequence. J Mol Biol 2000, 300:1005-1016.

15. Bendtsen JD, Nielsen H, von Heijne G, Brunak S: Improved prediction of signal peptides: SignalP 3.0. J Mol Biol 2004, 340:783-795.

16. Altschul SF, Gish W, Miller W, Myers EW, Lipman DJ: Basic local alignment search tool. J Mol Biol 1990, 21 5:403-4I0. 
17. Kolaskar AS, Tongaonkar PC: A semi-empirical method for prediction of antigenic determinants on protein antigens. FEBS Lett 1990, 276: 172-174.

18. Marchler-Bauer A, Anderson JB, Cherukuri PF, DeWeese-Scott C, Geer LY, Gwadz M, He S, Hurwitz DI, Jackson JD, Ke Z, Lanczycki CJ, Liebert CA, Liu C, Lu F, Marchler GH, Mullokandov M, Shoemaker BA, Simonyan V, Song JS, Thiessen PA, Yamashita RA, Yin JJ, Zhang D, Bryant SH: CDD: a Conserved Domain Database for protein classification. Nucleic Acids Res 2005:D 192-196.

19. Saha S, Raghava GP: Prediction of Continuous B-cell Epitopes in an Antigen Using Recurrent Neural Network. Proteins 2006, 65:40-48.

20. Saha S, Raghava GP: Prediction methods for B-cell epitopes. Methods Mol Biol 2007, 409:387-394.

21. Andersen $\mathrm{PH}$, Nielsen $\mathrm{M}$, Lund $\mathrm{O}$ : Prediction of residues in discontinuous B cell epitopes using protein 3D structures. Protein Science 2006, I 5:2558-2567.

22. Kulkarni-Kale U, Bhosle S, Kolaskar AS: CEP: a conformational epitope prediction server. Nucleic Acids Res 2005:WI 68-17I.

23. Buus S, Lauemoller SL, Worning P, Kesmir C, Frimurer T, Corbet S, Fomsgaard A, Hilden J, Holm A, Brunak S: Sensitive quantitative predictions of peptide-MHC binding by a 'Query by Committee' artificial neural network approach. Tissue Antigens 2003, 62:378-384

24. Guan P, Doytchinova IA, Zygouri C, Flower DR: MHCPred: bringing a quantitative dimension to the online prediction of MHC binding. Appl Bioinformatics 2003, 2:63-66.

25. Parker KC, Bednarek MA, Coligan JE: Scheme for ranking potential HLA-A2 binding peptides based on independent binding of individual peptide side-chains. J Immunol 1994, I52:163-175.

26. Singh H, Raghava GP: ProPred: Prediction of HLA-DR binding sites. Bioinformatics 200I, 17:1236-1237.

27. Saha S, Raghava GP: AlgPred: prediction of allergenic proteins and mapping of IgE epitopes. Nucleic Acids Res 2006:W202-209.

28. Fiers MW, Kleter GA, Nijland $H$, Peijnenburg AA, Nap JP, van Ham RC: Allermatch, a webtool for the prediction of potential allergenicity according to current FAO/WHO Codex alimentarius guidelines. BMC Bioinformatics 2004, 5:133.

29. Riaz T, Hor HL, Krishnan A, Tang F, Li KB: WebAllergen: a web server for predicting allergenic proteins. Bioinformatics 2005 21:2570-257I.

30. Wizemann TM, Adamou JE, Langermann S: Adhesins as targets for vaccine development. Emerg Infect Dis 1999, 5:395-403.

31. Bahl A, Brunk B, Crabtree J, Fraunholz MJ, Gajria B, Grant GR, Ginsburg H, Gupta D, Kissinger JC, Labo P, Li L, Mailman MD, Milgram AJ, Pearson DS, Roos DS, Schug J, Stoeckert CJ Jr, Whetzel P: PlasmoDB: the Plasmodium genome resource. A database integrating experimental and computational data. Nucleic Acids Res 2003, 31:2।2-215.

32. MalVac: Database of Malarial Vaccine Candidates A Community Resource [http://malvac.igib.res.in/]
Publish with Bio Med Central and every scientist can read your work free of charge

"BioMed Central will be the most significant development for disseminating the results of biomedical research in our lifetime. "

Sir Paul Nurse, Cancer Research UK

Your research papers will be:

- available free of charge to the entire biomedical community

- peer reviewed and published immediately upon acceptance

- cited in PubMed and archived on PubMed Central

- yours - you keep the copyright
BioMedcentral 